\title{
THE ROLE OF THE COURT OF JUSTICE OF THE EUROPEAN COMMUNITIES AS SEEN THROUGH ITS CASE LAW*
}

\author{
Maurice Lagrange $\dagger$
}

It is common knowledge that a "Convention relating to certain common institutions," signed and ratified at the same time as the Treaties of Rome, has entrusted to a single Court of Justice the jurisdiction of the Court of Justice that each of the three treaties-European Coal and Steel Community (E.C.S.C.), European Economic Community (E.E.C), and European Atomic Energy Community (Euratom)-has established. The same solution has been adopted in respect of the Assembly, which is a common organ of the three Communities. It has, however, been clearly provided that the single Court exercise its jurisdiction in accord with the procedure laid down by each of the three treaties-and depending on whether a claim is introduced within the framework of one or the other of the three instruments. The Treaties of Rome have not modified the E.C.S.C. Treaty in this respect; on the contrary, article 232 of the Treaty establishing the E.E.C. explicitly states that:

The provisions of this Treaty shall not affect those of the Treaty establishing the European Coal and Steel Community, in particular in regard to the rights and obligations of Member States, the powers of the institutions of the said Community and the rules laid down by the said Treaty for the functioning of the common market for coal and steel.

The importance of the part played under these circumstances by the Court in its capacity of sole judge and the difficulties resulting therefrom become at once apparent. The origin of these difficulties does not lie so much in the few differences that the treaties have introduced in respect to the submission of claims and to procedure (the same situation is rather frequent in municipal law, where the same judge may have to exercise different types of authority and apply different rules of procedure); they stem rather from some basic divergences in the very conception of the Common Market and in the economic rules on competition, discrimination, and so forth. The question arises whether the Court should undertake the interpretation of each Treaty in its original context, or whether it should, as far as the texts authorize it, take an approach to the problem that would permit an identical solution of similar conflicts. While such a result might appear desirable, it would be disappointing if it were accompanied by a slowing down of the normally more advanced integration of

- Translated from the French language by Mr. Jean-Aimé Stoll, Officer of the Court's Translation Service, Cour de Justice des Communautées Européennes.

+ Advocate General, Court of Justice of the European Communities, since 1958. Formerly Advocate General, European Coal and Steel Community, 1952-58. Contributor of articles to public 12\% and political science publications. 
the common market for coal and steel, and by a decrease of the powers of the High Authority of the E.C.S.C. ${ }^{1}$

However, at the time of writing, ${ }^{2}$ the Court has not had to pronounce itself on a claim arising under the Treaties of Rome. ${ }^{3}$ Its role may, therefore, be studied only within the framework of the Treaty concluded in Paris on April I8, I95I, instituting the E.C.S.C. In this respect, there exists no discontinuity between the Court of Justice of the E.C.S.C. and the single Court of Justice that has been substituted effective October 7, I958. With the exception of a few details, the rules of procedure have remained unchanged, and the proceedings that had already been instituted under the old Court have been processed without interruption under transitional rules. Continuity has been the more easily ensured as four of the seven judges, as well as the two advocates general and the registrar, have been transferred from the old Court to the new. ${ }^{4}$

In fact, the number of cases has increased at a regular rate; ${ }^{5}$ and their number, as well as the importance and variety of contested matters, have not only enabled the Court to create its own case law, but also, through this case law, to exercise considerable influence on the development of the Community.

\section{The Court's Role According to the Provisions of the Treaty}

\section{Article thirty-one of the E.C.S.C. Treaty establishes that}

The function of the Court is to ensure the rule of law in the interpretation and application of the present Treaty and of its implementing regulations.

In order to understand the true role of the Court of Justice, its place in the network of institutions established by the Treaty must be ascertained. The Treaty

1 A first interesting example of a confrontation of the two Treaties has arisen in an important case dealing with transport rates (elimination of special rates applicable to the transport of coal for the steel industry and of iron ore in the E.C.S.C.) In its two judgments of May I0, I960 (Government of the Federal Republic of Germany, Barbara Erzbergbau et al. v. High Authority, Dec. No. 19/58, 6/1 Recueil Officiel de Jurisprudence de la Cour 469 (I960) [hereinafter cited as Rec.]; Dec. Nos. $3 / 58$ to $18 / 58,25 \& 26 / 58,6 / 1$ REC. 362 (1960)), the Court exclusively applied the E.C.S.C. rules on nondiscrimination and the rules governing the establishment of the Common Market based on the "most rational distribution of production," which is obtained by the interplay of competition. It implicitly refused to take account of considerations of "regional policies," whereas article 80 of the E.E.C. Treaty provides that such factors must be considered for the authorization of special rates. In his final observations, the advocate general had advanced a rather more subtle argument, although he reached the same conclusion as the Court. See notes $42-45$ infra.

July, I96o.

${ }^{8}$ With the exception of some conflicts in matters of staff relations.

- For this reason, the present study quotes judgments rendered by the Court of Justice of the E.C.S.C. before Oct. 7, 1958, and those rendered after this date by the rew Court of Justice of the European Communities without distinction. Judgments are cited with the record number of the Court's Record office, the date, and the reference to the Recueil Officiel de jurisprudence de la Cour, published in Lusembourg.

${ }^{8}$ By July 15, r960, 154 appeals had been lodged, of which 28 had been withdrawn before judgment. One hundred and six judgments had been rendered, 20 cases were pending on that date. Taking into account the cases which represent interrelationships of a variable degree, one may estimate the number of strictly distinct cases judged by the Court at about 50 . 
establishes a Community composed of the various Member States, whose clearly defined task is, first of all, the establishment of a common market for coal and steel. To this effect, the Community ${ }^{8}$

must progressively establish conditions which will in themselves assure the most rational distribution of production at the highest possible level of productivity, while safeguarding the continuity of employment and avoiding the creation of fundamental and persistent .disturbances in the economies of the Member States.

In order to meet these ends the Treaty defines its objects ${ }^{7}$ and establishes prohibitive rules, ${ }^{8}$ as well as ways and means of action. ${ }^{9}$ Emphasis ought to be be laid on the fact that these rules concern the Community as a whole-that is to say, each of its institutions, and not only the High Authority. ${ }^{10}$

Thus, the Court appears as an internal judicial organ, the activity of which, within the field of its competence, aims at the smooth functioning of the Community legal order, and which partakes of the life of the Community. In examining the different aspects of the role of the Court in exercising the various powers conferred by the Treaty, this idea must constantly be kept in mind:

$x$. The main authority of the Court resides in its power to decide on claims for annulment, which Member States-and under certain conditions, coal and steelproducing enterprises (as well as interested third parties in certain cases)-may lodge against decisions of the High Authority. The High Authority is, in fact, the executive of the Community, and it is responsible for the application of the Treaty, in that it must ensure the normal play of competition according to the rules laid down by the Treaty, both by taking action adequate to attain Treaty objectives and by resisting the violation of prohibitive rules by states as well as by enterprises. To this end, the High Authority has been invested with certain powers, the exercise of which, from a formal as well as a material standpoint, has been carefully delimited in each case; the High Authority acts by taking decisions, individual ${ }^{11}$ or general, ${ }^{12}$ or by creating administrative rules within the framework of powers delegated to it by the Treaty. ${ }^{13}$ In respect of these decisions, the Court, whenever they form the subject of an appeal, exercises a control over their legality-a control similar to that

${ }^{\circ}$ E.C.S.C. Treaty art. 2.

${ }^{7} I d$. art. 3.

${ }^{8}$ Id. art. 4 .

${ }^{\circ}$ Id. arts. 5 and 6 . The most important of these latter is the following: "The Community shall assure the establishment, the maintenance and the observance of normal conditions of competition, and take direct action with respect to production and the operation of the market only when circumstances make it absolutely necessary." This constitutes no less than the outline of the Community's economic policy.

10 ". . Within the framework of their respective powers and responsibilities and in the common interest, the institutions of the Community shall ..." E.C.S.C. Treaty art. 3 .

${ }^{11}$ Authorization in matters of agreements and concentrations, see Nold v. Haute Autorité, Dec. No. ז8/57, March 20, 1959, 5 Rec. 89 (1958-59).

${ }_{12}$ Creation of a compensatory system, see Wirtschaftsvereinigung Eisen \& Stahlindustrie et al. v. Haute Autorité, Dec. No. I3/57, June 21, 1958, 4 REc. 286 (I958).

${ }^{18}$ E.g., regulation exempting certain concentrations from prior authorization, art. $66(3)$. 
of the municipal legal systems of Member States, of which the most commonly known is the recours pour excès de pouvoir [appeal against abuse of power] instituted before the Conseil d'Etat of France. As a matter of fact, claims for annulment may be instituted not only against positive decisions, but also against explicit or implicit refusal of the High Authority, after suitable request, to make a decision in cases where it is alleged that the High Authority, by virtue of the Treaty, was under an obligation to act; this is known as recours en carence.

2. Apart from the jurisdiction to decide on claims for annulment, the Court exercises in certain cases a "full jurisdiction"-i.e., an unlimited authority to consider all the aspects of the case. The most important of these cases involves the sanctions against enterprises and against Member States. The High Authority may impose fines and daily penalty payments on enterprises alleged to have violated their obligations; and these enterprises may appeal to the Court, which has full powers to consider the case both in fact and in law; this includes the right to consider the amount of the fine. A special procedure is provided where a Member State has violated one of the obligations relating to the Treaty, ${ }^{14}$ This sanction applies equally to positive acts, such as the grant of illicit subsidies or other means of assistance, ${ }^{15}$ and to omissions, such as the nonexecution by a Government of a decision of the High Authority during the course of an appeal. ${ }^{16}$ Here, again, the appeal en carence may be resorted to: A Member State or an enterprise may request the High Authority to declare that a Member State has violated one of its obligations, and go to the Court if the High Authority refuses to act. ${ }^{17}$ As to questions both of fact and of law, proceedings instituted against a Member State under article eighty-eight for a failure in fulfilling its Treaty obligations are of great importance. These proceedings enable the Court to pass on questions that, in themselves, as well as in respect of the principles to which they relate and the interpretation of the Treaty which they render necessary, are of utmost significance. This is especially true since the application and implementation of the Treaty often depends on action to be taken by the Member States, rather than on the exercise of the High Authority's powers.

3. The Court is invested with additional powers-e.g.:

a. to decide on damages where the responsibility of the Community institutions or their staff is involved; ${ }^{\mathbf{1 8}}$

b. to decide on conflicts between the staff and the administration of the Com-

14 E.C.S.C. Treaty art. 88.

${ }^{15}$ E.g., creation by the Federal Government of a special allowance for underground miners subsidized by the State, Association des Charbonnages Réunis du Limbourg, Dec. No. I7/57, Feb. 4, I959, 5 REc. II (1959).

${ }_{10}$ Decisions of the High Authority are not suspended in effect prior to judgment when contested by appeal, unless the Court orders their suspension; see E.C.S.C. Treaty art. 39; Government of the Federal Republic of Germany v. High Authority, Dec. No. 3/59, March 8, r960, 6/I Rec. I7 (1960).

${ }^{17}$ Groupement des Industries Sidérurgiques Luxembourgeoises v. Haute Autorité, Dec. Nos. 7 and 9/54, April 23, 1956, 2 REc. 53 (1956).

${ }_{18}$ E.C.S.C. Treaty art. 40. Several claims for damages have been made on this basis by various steel producers against the High Authority, for alleged faults in the control of the compensatory arrangement for imported scrap iron, which has given rise to considerable fraud. One judgment has been rendered F.E.R.A.M. v. Haute Autorité, Dec. No. 23/59, Dec. I7, 1959, 5 Rec. 501 (1958-59). 
munities' institutions; the role of the Court in this respect is that of an administrative tribunal similar to those instituted by the United Nations and the International Labor Organization; ${ }^{\mathbf{1 9}}$

c. to annul the acts of the Assembly or the Council of Ministers at the request of a Member State or the High Authority; this power is limited, however, to claims founded on lack of legal competence or substantial procedural violations and has not been exercised to date; and

d. to render an advisory opinion on the constitutionality of amendments to the Treaty that the Assembly may propose under certain determined conditions, at the request of the High Authority and with the concurrence of the Council of Ministers expressed by a majority of five members. ${ }^{20}$

This short summary of the Court's principal functions shows the twofold aspect of its role:

I. On one hand, the Court is responsible for ensuring the legality-that is to say, the conformance with the Treaty-of the action of the Community's organs, especially the executive and the Member States. To these latter, the Court represents a guarantee against any arbitrary acts and abuse of power by the High Authority. Conversely, it enables the High Authority to guard itself against interference by the States or against their refusal to honor their pledge of cooperation in the application of the Treaty. The functions of the Court in this regard can, therefore, be summarized as follows:

a. to ensure that the Community does not exceed the limits of the delegation of sovereignty consented to by the Member States; and

b. to enable the Community to exercise the powers so delegated whenever the States resist such exercise; if necessary, the Court may obligate the Community to exercise its powers (the Court appears, therefore, to have been invested with the functions of a constitutional court and, to the extent that the Treaty may be assimilated to a federal system, it can be stated that the role of the Court resembles closely that of a court exercising a federal jurisdiction).

2. On the other hand, the Court is entrusted with the protection of individual rights against the arbitrary and the illegal action of the Administration, and its role in this respect is identical with the functions that the different Member States of

${ }^{10}$ Fourteen judgments have already been rendered in this type of case, of which several are in favor of the claimants. See e.g., Kergall v. Common Assembly, Dec. No. I/55, July 19, 1955, 2 REc. II (1956), where the Court has elaborated a bold theory relating to the "prestatutory character" of a situation founded on a "public law contract," which entitles employees to stability of employment; Miranda Mirossewich v. High Authority, Dec. No. 10/55, Dec. 12, x956, 2 REc. 365 (1956), in which the Court has annulled a decision refusing a permanent contract to a trainee, on account of the manner in which the traineeship had been accomplished (following the judgment, the traineeship was renewed; and this time the claimant was granted permanent appointment).

${ }^{20}$ E.C.S.C. Treaty art. 95. This procedure has already once been applied, and has resulted in the amendment of a very important Treaty clause, i.e., article $5^{6}$, concerning grants-in-aid for the readaptation of manpower rendered unnecessary by the structural changes of the coal market. Opinion of March 4, rg60, 6/1 Rec. 93 (1960). 
the Community have conferred on either administrative or regular tribunals. In fact, the creation of the Treaty and the delegation to supranational organs (particularly to the High Authority) of powers exercised hitherto by national authorities has partly deprived certain citizens of the legal protection otherwise enjoyed in their own countries: national judges are no longer competent to protect them. By ensuring that the supranational authorities exercise their powers in conformance with the Treaty, the Court of Justice substitutes itself for the national judge in affording the legal protection to which these citizens of the Member States continue to be entitled, although certain jurisdiction has been transferred to the Community. This is particularly true whenever the High Authority makes use of its right to impose fines or to levy contributions by way of self-executing decisions that are not subject to consideration by national judges. In this sense, it may be said that the legal order of the Community, which represents the common weal of the Member States, incorporates itself into each municipal legal order; and the Court of Justice itself must be considered, in each Member State, as the complement of the municipal judiciary.

\section{II}

\section{How the Court has INTERpreted Its Functions}

In the following discussion, it is intended to demonstrate how the Court has exercised the functions conferred upon it by the Treaty. First, investigation will be made of the conditions under which the Court has granted access to its forum to claimants other than the States. Then inquiry must be made into the Court's contribution to the solution of some of the most important problems with which it has had to deal.

\section{A. The Direct Access to the Court by Private Individuals}

From the beginning, it has become apparent that enterprises, associations of enterprises, and individuals freely instituted proceedings before the Court against-sometimes important-decisions of the High Authority. Proceedings instituted by Member States, however, remained rather the exception. What are the causes underlying this situation?

The main cause of this phenomenon lies in the rather fortunate fact that conflicts arising between the interests of one or more other Member States are rather infrequent, whereas the interests of different economic or social groups are more likely to clash. A decision may be taken with the unanimous consent of Governments and still seriously damage the interests of a whole trade or profession, such as the coal producers. ${ }^{21}$ Another reason is the increasing role assumed in fact by the Council

${ }^{21}$ E.g., the appeal made by the Federation Charbonnière de Belgique and a certain number of Belgian coal industries against a decision of the High Authority concerning the distribution of funds made available under the compensatory arrangement (mécanisme de péréquation) in order to enable the Belgian coal industry to face the common market after the expiration of the transitional period. Fèdèration Charbonnière de Belgique v. Haute Autorité, Dec. No. 8/55, July I6, I956, 2 REC. I33 (1955-56); Société des Charbonnages de Beeringen et al. v. Haute Autorité, Dec. No. 9/55, July I6, x956, 2 REc. $323(1955-56)$. In his final observations, the undersigned Advocate General stated: "Associations of 
of Ministers in the preparation of decisions by the High Authority. Even in the normal case, where the concurring opinion of the Council is not required, these decisions are generally preceded by extensive common research, or at least by consultations in close liaison with the Council or its Coordinating Committee-which is composed of national civil servants responsible for preparing the sessions of the Council, and which, although not provided for by the Treaty, plays, in fact, a very important role. This procedure results frequently in an effective agreement among the members of the Council, and between these latter as a body and the High Authority. It goes without saying that a minister who has expressed his agreement with a decision that, at least on the essential points, takes into account the concerns of his own government, will, in most cases, hesitate, on behalf of this very same government, to attack this decision on the very day of its publication. Under these circumstances, the interested parties are left alone to defend themselves against these "negotiated decisions," which, notwithstanding their thorough preparation, may well turn out to be illegal. Thus, we have the paradox that the maintenance of state influence within the Community in a larger proportion than was intended by the Treaty calls for a more extensive direct protection of private individuals than had been thought necessary.

The enterprises' right of appeal is rather strictly delimited by article thirty-three of the E.C.S.C. Treaty. Thus, enterprises may only attack

individual decisions and recommendations affecting them, or . . . general decisions and recommendations which they deem to involve an abuse of power affecting them.

The state is considered responsible for the normal safeguarding of its nationals' interests. This is a principle of international law that has been maintained in the Treaty.

Experience has shown, however, that if the Treaty has revealed itself in respect of the functioning of the executive to be somewhat less supranational than one might have expected, it certainly is very supranational in regard to its direct intervention in the functioning of the Community's enterprises, the Community's "subjects." In fact, whatever may be the circumstances in which the High Authority takes its decisions, these are published in the Official Gazette and thereby become self-executing. Hence the normal reaction of the victim is to go to Court; and hence also the emphasis on the Court's role as the municipal judge-a role which has already been underlined.

enterprises referred to by article 48 are called upon to play an important role under the Treaty, and this role is defined by article $4^{8}$ itself. We deem it absolutely necessary that they be allowed to play this part also when it comes to defend in the law the collective interests which they represent, and this all the more since-as experience proves-certain decisions of the High Authority may violate these lawful interests, while no Member State deems it necessary to appeal. It may cven be said, with regard to coal, that such is almost the normal situation, because usually, and particularly in matters of prices, the interests of the coal producers simultaneously conflict with those of the High Authority whose duty it is to 'seek the establishment of the lowest possible prices' (art. $3(\mathrm{c})$ ), with those of all the consumers, particularly those of the steel producers, and with those of the Governments, whose general policy also tends, in most cases, to reduce the prices of this raw material." 
This gives rise to inquiry about the Court's attitude with regard to this development. The question is whether the Court's attitude has been a rigid, negative one, or whether, to the contrary, the Court, inspired exclusively by considerations of equity, ignores the Treaty system and the legal principles which it contains. If the Court had chosen the first solution, it would have been oblivious to the fact that the chief task of a judge is to do justice, and that the Court is one of the organs of the Community, which, by virtue of article three of the Treaty, are under the obligation to realize the objectives laid down therein. In the second case, the Court would have ignored its task, as defined by article thirty-one, to safeguard the respect of law in the interpretation and the application of the Treaty.

Confronted with this dilemma, the Court has tried as far as possible to foster an economic and political development which has become manifest, without, however, prejudicing the Treaty system, and without modifying the legal principles which it contains. It is on this basis that the Court has tried to open its forum as much as possible to private persons. It has been little inclined to attach undue importance to rules of procedure, e.g., as regards the grounds of appeal. ${ }^{22}$ Likewise, it has not been very demanding with regard to the grounds of decisions of the High Authority, ${ }^{23}$ except in cases where it considered that clearly defined grounds were necessary in order to allow the Court to exercise the jurisdiction conferred on it by the Treaty. ${ }^{24}$ Sometimes the Court has had recourse to literal interpretation: in considering the tenor of article thirty-three (enterprises or their associations "shall have a right of appeal against general decisions which they deem to involve an abuse of power affecting them"), the Court declared that "according to this text, which is perfectly clear, admissibility of the claim is sufficiently established if the claimant formally alleges an abuse of power affecting him."25

The attitude of the Court is illustrated by another example concerning the application of article thirty-three, which provides that enterprises and associations may appeal "against individual decisions and recommendations concerning them." The Court has decided that it is sufficient for the decision "to present the character of an individual decision, although the decision may not be an individual one in respect of the claimant," provided the latter is affected. ${ }^{20}$ The Court referred in this case

${ }^{22}$ Compagnic des hauts fourneaux de Chasse, Dec. No. 2/57, June 12, 1958, 4 Rrc. I46 (I958).

${ }^{23}$ Government of the Kingdom of the Netherlands v. High Authority, Dec. No. 6/54, Mar. 2r, 1955, I Rec. 20I (1954-55); Geitling v. Haute Autorité, Dec. No. 2/56, Mar. 20, x957, 3 Rec. 36 (1957).

${ }_{26}$ This goes for the application of art. 65(2), which lays down quite restrictively what are the conditions under which agreements may be authorized. Nold v. Haute Autorité, Dec. No. 18/58, Mar. 20, 1959, 5 Rec. Ix6 (1958-59); Comptoirs de la Ruhr et Nold v. Haute Autorité, Dec. Nos. 36-38/59 \& $40 / 59$, July $15,1960,6 / 2$ Rec. 852 (1960).

${ }_{20}$ Assider v. Haute Autorité, Dec. No. 3/54, Feb. Ir, I955, I Rec. I38 (I954-55).

${ }^{20}$ Groupement des Industries Sidérurgiques Luxembourgeoises v. Haute Autorité, Dec. Nos. $7 / 54$ and 9/54, 2 Rec. 87 (I956). This was an appeal against an (implicit) decision of the High Authority in refusing to take steps against the Government of Luxembourg for having authorized a public official to increase the price of coal intended for other than household purposes-actually the coal exclusively used by the steel industry, since the industrial uses of coal in Luxembourg are almost entirely limited to the steel industry. 
to the principle of "interest" which, although not explicitly mentioned in the Treaty, is the underlying principle of the claim for annulment, as the Advocates General have noted on several occasions. ${ }^{27}$ Usually the Court has tried, whenever possible, to hold itself to the text of the Treaty. However, in cases where the latter does not furnish adequate grounds for standing to appeal, it does not hesitate to invoke the principle of "interest." 28 Thus, the Court interprets a rigid and careful text on the basis of general principles of municipal law of the Member States.

Consider another example of the Court's attitude. With regard to the formal character of a decision, the Court has decided, in its judgments ${ }^{29}$ relating to compensatory arrangements in Belgium, that a simple letter of the High Authority published in the "Information" section of the Official Gazette, must be considered parte in qua as a decision liable to appeal. Still a further example: concerning the objection of illegality, the Court has adjudged ${ }^{30}$ that, in view of the lacunae in the texts directly applicable-and after rejecting the argument to the contrary which might have been drawn from another Treaty rule (i.e., article thirty-six relating to pecuniary sanctions, which provides expressis verbis the objection of illegality)the enterprises might, in the course of an appeal against an individual decision, raise an objection of illegality as to those general decisions on which the attacked decision had been based. Moreover, in this situation, they were authorized to invoke against such general decisions all the grounds enumerated in article thirtythree and not merely the "abuse of power affecting them," which is the only ground they would be allowed to invoke in case of a direct appeal. This decision is of great importance, since, in effect and by way of exception, it confers the same rights on the enterprises to contest the legality of the executive's decision as are possessed by the Member States.

\section{B. Study of Some Specific Cases}

Having thus established that the Court has widely granted access to its forum, and that the claimants have made an equally extensive use of this facility, it will be interesting to demonstrate, by a few examples, how the case law of the Court has been formed and the part such case law has played both in the creation of Treaty law and in the development of the Community's activities.

I. The so-called "Price-List" case was the first case submitted to the Court. ${ }^{31}$ Article sixty of the E.C.S.C. Treaty, dealing with prices, prohibits:

... discriminatory practices involving within the common market the application by a

${ }^{27}$ See Final Observations by Advocate General K. Roemer in Groupment des Industries Sidèrurgiques Luxembourgeois v. Haute Autorité, Dec. Nos. 7 \& 9/54, April 23, 1956, 2 REc. 123-26 (1955-56). Final Observations by Advocate General Lagrange in Fèderation Charbonniére de Belgique va Haute Autorité, Dec. No. 8/55, July I6, I956, 2 Rec. 267 (1955-56).

${ }^{28}$ See the judgments already cited, stupra note 26 .

${ }^{29}$ See note 21 supra.

${ }^{30}$ Compagnie des Hauts Fournaux de Chasse, Dec. No. 15/57, June 12, 1958, 4 Rec. x86 (1958); Meroni, Case No. 9/56, June 13, 1958, 4 Rec. 25 (1958).

${ }^{31}$ Government of the French Republic et al., cases I to $4 / 54$, Dec. 21, I954, I REc. 10 (1954-55). 
seller of unequal conditions to comparable transactions, especially according to the nationality of the buyer.

and, in order to ensure this prohibition, establishes that

... the price-lists and conditions of sale applied by enterprises within the common market shall be published to the extent and in the form prescribed by the High Authority.

Originally the High Authority had, by way of administrative regulation, ordered the publication of price lists and conditions of sale, and had prohibited the application of prices differing from those published; increases and decreases of prices had to be preceded by appropriate and published amendments of the original or preceding price-list. However, the High Authority soon realized that steel producers practiced, in fact, a discount policy which involved sometimes very important discrepancies between the actual price and the price-lists; this practice was motivated by the economic recession which was prevailing in 1953 . The High Authority could, of course, have pronounced sanctions; but these would have had to be invoked against practically all enterprises of the common market. In turn, this would undoubtedly have jeopardized the application and life of a Treaty which had hardly begun to become a reality. On the other hand, if the violation by the enterprises of the rules relating to publicity was subject to criticism, it actually reflected in a better way the play of competition than would the artificial application of prices higher than market prices. Thus, the High Authority searched for the means of reconciling the application of the publicity rules, which it considered an essential weapon to eliminate discrimination, with the maintenance of effective competition; and, to this end, it allowed a $2 \frac{1}{2}$ per cent tolerance in the application of the pricelists. This became known later as the "rabais Monnet" (Monnet's Discount). The Court annulled this decision as being contrary to the Treaty; in doing so, it disagreed with the present writer who, as Advocate General, expressed the opinion that the High Authority's interpretation of the Treaty might have some merit.

The importance of this first judgment of the Court is striking. From the outset the Court has had to deal with one of the most delicate problems of market economy, i.e., the relation between competition and nondiscrimination. From this, certain commentators have drawn the conclusion that according to the Court's interpretation of the Treaty, there exists a contradiction between the two principles and that, in opposition to the E.E.C. Treaty, the Coal and Steel Treaty establishes the priority of nondiscrimination over free competition. ${ }^{32}$ This theory certainly does not correspond to the intention of the authors of the E.C.S.C. Treaty, who have not considered publicity of prices as an obstacle to the establishment of rules for normal competition, but on the contrary, as a means towards achieving this end. In truth, the problem relates rather to agreements, because, while it is relatively easy to control the application of publicity rules, ${ }^{33}$ it is much more difficult to detect and to

\footnotetext{
${ }^{32}$ This theory has been advocated, particularly at the important International Conference on AntiTrust Law, held in Frankfurt from June 7 to 11,1960 .

${ }^{88}$ The High Authority exercises a careful control on this subject and does not hesitate to apply
} 
eliminate agreements between producers if, for instance, all producers of one country issue simultaneously price-lists which are similar. Moreover, the term "common market" must not be considered as being synonymous with "single market"; there can be no doubt that, even in the steel industry, ${ }^{34}$ there remains a certain isolation of national markets, despite the elimination of customs tariffs, quantitative restrictions, subsidies and other obstacles which have been abolished by the Treaty. In fact, the potentialities of competition created by the Treaty, however active and beneficial they are, concern the several industries within the national territories, rather than all enterprises of the six countries, each taken by itself.

The Court's judgment is no less instructive if it is considered from a purely legal aspect. The Court had been confronted with one of the classic problems of treaty interpretation-with a conflict between law and opportunity, rather than between the letter and the spirit of the Treaty. It is interesting that the Court was not satisfied by a construction founded on a literal interpretation, but that it did use a whole series of arguments in order to establish that the result at which it arrived was the (probably regrettable) effect of a coherent system established by the Treaty and logically inserted in its body of rules.

On a different and, with respect to a general analysis of the Treaty, probably still more important issue, the Court stated that, in taking measures for the application of specific Treaty rules (i.e., article sixty on prices) the High Authority is not only entitled, but under obligation, to pursue the aims defined in the preliminary articles two, three, and four (establishment of lowest prices, fight against illegal agreements, etc.) and that article sixty on prices may be resorted to in order to sustain action taken against agreements. Thus, from its very first judgment onwards, the Court has been careful not merely to limit itself to a literal textual interpretation, but instead to consider the Treaty as a whole and to recognize the interrelation of the Treaty rules. This attitude has been of the utmost importance for the application of an economic treaty, since it is self-evident that in this field a specific problem may present itself in numerous aspects, each of which may be subject to different legal norms.

2. This position was expressly reiterated in the next decision, ${ }^{35}$ in which the Court considered that the existence of a situation which possibly justified the application of article $66(7)$ (predominant market position obtained by public or private enterprises with the result of eliminating effective competition) did not itself bar the High Authority from exercising the powers which article 6I(a) (establishment of minimum prices) confers upon it.

\footnotetext{
sanctions to such enterprises as apply prices differing from their price-lists, or whose price-lists contain omissions. See $1 / 59$, Macchiorlatti Dalmas e figli v Haute Autorité, Judgment of Dec. 17, 1959, 5 Rec. 415 (1959).

"We do not even mention the coal industry, as to which it is common knowledge that the common market is very far from being a reality.

${ }^{35}$ Government of the Kingdom of the Netherlands, Dec. No. 6/54, March 21, I955, I Rzc. 222 (rg5455).
} 
3. In connection with legal conflicts arising over scrap iron, two interesting cases ought to be mentioned.

(a) The High Authority had created a financial arrangement for the supply of scrap iron to the common market, in order to avoid the rise of prices of scrap iron of internal origin in relation to those of scrap imported from third countries, particularly the United States. ${ }^{36}$ The relevant decision had been taken pursuant to article fifty-three of the Treaty, which reads as follows:

... the High Authority may:

(a) after consulting the Consultative Committee and the Council, authorize the institution, under conditions which it shall determine and under its control, of any financial mechanisms common to several enterprises which are deemed necessary for the accomplishment of the missions defined in Article $3 \ldots$;

(b) with the concurrence of the Council acting by unanimous vote, institute itself any financial mechanism satisfying the same purposes as referred to above. (Emphasis supplied.)

The High Authority had applied the last rule, which rendered the financial arrangement obligatory. The management of this arrangement had been entrusted to a private body established by the major steel producers of the Community, whose decisions, provided they were taken unanimously, were final. The High Authority retained merely the right to veto. However, some of these decisions, such as the establishment of the compensatory price, clearly exceeded the powers of management and, through the exercise of prerogatives clearly reserved to the High Authority, constituted an authentic market intervention. The mere failure to veto cannot be considered as being equivalent to a decision taken by the High Authority as a collective body in conformance with the procedure prescribed, and under the safeguards established by the Treaty.

Consequently, the Court has rejected the above procedure on the grounds that it entails a delegation of powers by the High Authority to a private body. ${ }^{37}$ This decision, which from many viewpoints appears as a rejection of professional dirigisme, has in this respect drawn due attention from all concerned within the Community. Lawyers will appreciate this judgment in view of the important contribution to legal science by a decision which, in applying to the Community a theory about the delegation of powers, influences directly the balance of powers established by the Treaty, and, in so doing, touches on the very scope and conditions of delegation of the powers underlying the Coal and Steel Community. The problem is truly one of federal constitutional law, and this appears with particular clarity if account is taken of the fact that it is a private person, a subject of the Community as well as of a Member State, which receives the safeguard of rules created for the benefit of these

\footnotetext{
${ }^{30}$ As had been expected, the entry into force of the common market created a certain strain on the internal scrap iron market, particularly in Italy, which has no ore mines and has been traditionally a great consumer of scrap iron. Supplies used to be imported frecly into Italy from France and Germany, but their resources, formerly in excess of demand, became insufficient. From 1955 onwards, the situation became disquieting because of the considerable increase of the "composite price" of American scrap iron. For some time now, the strain has lessened. The compensatory arrangement has not been extended and is at present being liquidated.

${ }^{21}$ Meroni v. Haute Autorite, Dee. No. 9/56, June 13, 1958, 4 REc. 36 (1958).
} 
"double allegiance" subjects-rules which trace the limits of the power of the "Federal Executive" and lay down the conditions under which it may be exercised.

(b) The second case touches on the substance of the matter. In a first phase, the problem was one of a "simple compensation" between imported scrap iron prices and prices of "internal" scrap iron; compensation was paid on a quantitative pro rata basis. It soon turned out, however, that the moderate prices which were the result of the arrangement expanded, rather than decreased, the demand for this scarce raw material. The very effect of compensation turned out to render the normal functioning of the price mechanism impossible.

Hence came the plan to modify the arrangement, so as to encourage the economizing of scrap iron "without, however, rendering the establishment of new steelproducing centers more difficult." This was obtained by modifying the criterion for distribution of the compensatory funds; these were no longer to be distributed on a tonnage pro rata basis, but in an unequal manner, which tended to penalize use of scrap iron deemed excessive in relation to a determined period of reference. The purpose was to obtain an increase in the consumption of pig iron. This modified arrangement was at the heart of a series of appeals introduced by the Belgian, German, and French steel industries.

These appeals were principally based on the following grounds:

r. Violation of article three, particularly as regards the Community's obligation to:

(c) seek the establishment of the lowest possible prices,

(d) ensure that conditions are maintained which will encourage enterprises to expand and improve their ability to produce.

The above rules were invoked in the first place by steelworkers using the Martin and electrical processes, since, to them, scrap iron practically represents the sole raw material which can be used. The High Authority did not fail in their reply to invoke other goals equally established by article three-for example, the goal which obligates the Community "to promote a policy of rational development of natural resources, while avoiding undue exhaustion of such resources." This rule, mutatis mutandis, may be so construed as to apply to scrap iron-which, to the steel producer, is as much a raw material as is iron ore.

2. Discrimination.

3. Violation of certain specific rules, particularly article fifty-eight, on shortages. In this respect, the High Authority was criticized for having used a financial arrangement (relevant under article $53(\mathrm{~b})$ ) in order to correct a shortage (whereas this situation was deemed covered by article fifty-nine); avoiding thereby the ad hoc procedure; and, by so doing, depriving the enterprises of the safeguards provided for by this article (which may be defined as a sort of "procedural abuse").

The Court approved the High Authority's decision and declared: ${ }^{38}$

${ }^{88}$ See Groupement des Hauts Fourneaux et Aciéries Belges et al., Dec. Nos. 8 to $13 / 57$, June 21, 1958, 4 REc. 223 (1958). (Emphasis supplied.) 
In pursuing the aims of article three of the Treaty, the High Authority must, in eventual conflicts, ensure permanent conciliation between these aims considered individually and, whenever such conciliation is impossible, grant a temporary preference to such aims as may appear appropriate in the light of facts or economic circumstances in view of which the High Authority, when carrying out the task assigned by article eight of the Treaty, takes its decisions.

After determining the meaning of the term "financial arrangement" in the wording of article fifty-three, the Court continued:

... whereas the High Authority may, by making appropriate use of this powerful means of intervention, ensure to a very great extent, subject to the needs of the situation, the necessary conciliation of the aims of article three of the Treaty within the framework of the task assigned to it by the Treaty, and whereas conversely the powers delegated to this end to the High Authority are limited by specific rules contained in Title III of the Treaty; whereas, in particular, such powers must be considered to have been used for illegal ends if it appears that the High Authority has used them exclusively, or at least chiefly for the purpose of avoiding a procedure specifically laid down by the Treaty in order to meet the situation with which it has to deal ....

Thus, the Court rendered an exhaustive interpretation of one of the Treaty's basic articles (article three) and to this end used the concept of reconciling legal goals whose concurrent application creates conflicts. Thus was employed one of the most efficient tools of administrative tribunals; ${ }^{39}$ and only thereafter has the Court searched for the legal source of the power conferred on the High Authority for such purposes. Finally, the Court undertook to set the limits of this power by using a conception of legal technique well known to the specialist-i.e., the "détournement de procédure."

This case illustrates the role of the Court, not in its capacity of "economic judge," but as an administrative tribunal deciding in economic matters. The Court does not choose between laissez-faire liberalism and dirigisme; it does not create a doctrine. By interpreting the Treaty in a coherent manner, and by construing it so as to enable the Executive to attain the aims of the Community, the Court limits its role to that of ensuring that the different Community institutions exercise their powers in accord with the Treaty.

4. One last example will be gleaned from some very recent cases on transport matters. The difficulty in this field stems from the fact that the Coal and Steel Treaty realizes merely partial integration of coal and steel. The transport pool, which had been envisaged at the same time as the Schuman Plan, has not been translated into reality. The Treaty merely provides for a limited intervention by the High Authority, and leaves the task of eliminating discriminations in the transport of coal and steel, as well as that of harmonizing transport rates, to the Governmentswhich, moreover, in all other matters pertaining to general transport policy, retain

${ }^{89}$ One of the classic examples of the application of this theory may be found in the case law of the French Conseil d'Etat, concerning the reconciliation of the powers of police with the protection' of individual rights. 
their unfettered sovereignty. Thus it is within the framework of the E.E.C. Treaty that the general transport problem will have to be solved. The sole direct power conferred on the E.C.S.C. High Authority concerns special freight rates created for the benefit of coal and steel producers; and these rates must be submitted to the High Authority for approval. In all other matters, the role of the High Authority is limited to that of coordinating and possibly of discerning discriminations; but it does not include the power of imposing a rate system on Member States. Nevertheless, due to the efforts of a Committee composed of experts from the six Member States and inspired by the High Authority, substantial results at first were achieved in the elimination of discriminations within national systems and in the establishment of direct international rates of a digressive character and exempt from the usual procedure of "breaking" the rates on crossing national boundaries.

However, with regard to special domestic rates for transport of ore and coal by rail to the steel industry, the High Authority was less fortunate. After extended exchanges of opinion with the interested Governments and after investigations on the spot, a series of decisions were made on February 9, 1958, ordering the suppression of all rates considered as "supporting rates," while approving at the same time the maintenance of a certain number of other rates, justified by different reasons, such as the existence of competing means of transport. According to the High Authority, the reasonable solution would have consisted in establishing in Germany special rates for whole trains, as had already been done in France and in Belgium; but the High Authority did not have the power of imposing this solution on the German Government and could only "recommend" it- to no avail.40

The decision concerning German rates was appealed by the West German Government, seconded by the interested Länder, as well as by a whole series of German steel producers who had benefited from the suppressed special rates. On the other hand, the decision was supported by the steel producers of Lorraine, supported by the French Government. The Lorraine steel producers argued that, in reality, the special rates of the German Bundesbahn constituted, in toto, a discriminating rate system, since, in fact, the transport of coal from the Ruhr to Lorraine was subjected to the general rates. ${ }^{41}$ On the other hand, the Germans protested against the abolition of certain special rates, because they were persuaded that these rates were justified for particular reasons.

This conflict has given rise to several important judgments. First it was ruled ${ }^{42}$ that the course of action taken by the German Government in refusing to execute the decisions of the High Authority until judgment in this case had been rendered was

${ }^{10}$ It is known that the Bundesbahn-the German rail system-is not autonomous in matters of transport rates; these must be approved by the federal government. Traditionally, the "freight rates policy" has been' an instrument of the government in the service of the latter's general economic policy; it has been used particularly to assist certain industries situated in economically disadvantaged regions, such as Siegerland.

${ }^{11}$ It is common knowledge that the steel industry of Lorraine, situated nearby the iron ore reserves of Lorraine, depends largely on the Ruhr for its supplies of coke.

"Government of the Federal Republic of Germany v. High Authority, Dec. No. 3/59, Mar. 8, x960, 6 REC. II7 (I960). 
illegal. ${ }^{48}$ The Court stated that the decisions of the High Authority take effect evem as to Member States, unless and until the Court has ordered the execution of the decision to be suspended. On the merits, the appeals were rejected. The Court. declared that "it would be contrary to the spirit of the Treaty to authorize speciall rates on the sole ground that adaptation of the interested enterprises to the common market appeared difficult or impossible." ${ }^{.44}$ This implied the rejection of the so-called "supporting" rates. It also entailed the implicit rejection of "regionalism" within the framework of the Coal and Steel Treaty.45 Special rates cannot be justified except in special circumstances, for reasons inherent in the transport enterprises themselves, such as established competition by other means of transport like water transport (this did apply to certain rates).

Those judgments are interesting not only from the legal standpoint, but also. because of their consequences. In fact, the federal government did not await thejudgment in re Siderurgie lorraine $e^{46}$ in order to study a system of rates by wholetrains; at the time of writing, these rates are about to be introduced and will grant substantial reductions applicable without any discriminations whatsoever as to any transport of coal to the steel producers, including those situated in Lorraine. This

\footnotetext{
48 Government of the Federal Republic of Germany v. High Authority, Dec. No. 19/58, May ro, 1960, 6/1 Rec. 469 (1960); Barbara Erzbergbau et al. v. Haute Autorité, Dec. Nos. 3-18/58, $25 \&$ 26/58, May ro, 1960, 6/1 Rec. 367 (1960).

"For his part, the present writer stated, in his final observations (6/Y REc. 44I (Ig60)): "One of the basic principles which, in the minds of the authors of the Treaty, condition the common market is that of equality under 'natural' conditions, and particularly of maintaining what has been called? 'geographic protection.' Here we meet with the fundamental error committed by most of the claimants who base their reasoning on the assumption that transport rates could-or even must-consider the location of enterprises, as a determining factor, and adapt themselves accordingly. But, in our opinion, theopposite is true; the transport is the determining factor to which enterprises must adapt themselves, and tranisport must be so organized as not to be discriminating, the suppression of discriminations may eventually entail structural changes and relocation of production units; it being understood that all: necessary steps will be taken to minimize the more violent effects of such relocation. This is the condition to which the Treaty subjects the task of progressively establishing 'conditions which will in themselves. assure the most rational distribution of production at the highest possible level of productivity' (art. 2), that is to say, an effective common market of raw materials proportionate to Europe."

"While admitting that neither the High Authority nor the Court is in a position to judge theeconomic soundness of a Member State's regional policy, the Advocate General expressed the opinion that a "supporting" rate might perhaps be justified, from the carrier's point of view, in cases where, in: consideration of other existing measures of regional assistance, this rate represented a temporary measure of assistance which was supposed to disappear on the day the regional policy had obtained results and enterprises would be in a position to accept application of normal rates. Thus, the special rate would haveto be considered as a measure justified to preserve customers which might turn out to raise the cost of transport above marginal levels, and could not, in this case, be considered as a subsidy prohibited by the" Treaty, or as a discrimination. However, in the case referred to, the above conditions had not been meteither because of failure on the part of the enterprises to prove that they were not in a position to pay normal rates (transport of coal from the Ruhr to the Siegerland industries) or because the need for assistance was of a permanent character (transport of iron ore).

"The judgment was read in public sittings on July 15, r960. As had been expected after thejudgment of May Io, on the German claims, the main argument of Sidérurgie lorraine has been rejected. The suppression of unauthorized special rates has resulted in the greater part of the internal German traffic being subject to the basic rate which hence becomes in fact, and not merely in law, a genieral ratewithout discriminating character. Claimants have nevertheless obtained partial satisfaction since the Court: admitted, after hearing the experts, that certain rates aimed at competition with fluvial transport had not been correctly computed. (Chambre syndicale de la noterurgie de l'Est de la France et al. v. Haute: Autorité, Dec. Nos. $26 \& 36 / 58,6 / 2$ REc. 573 (I960).)
} 
solution had at all times been championed by the High Authority, which could, however, not impose it. Thus, a problem has been solved in a field where the powers of the High Authority are especially limited-a problem in regard to which responsible governments, due to the divided opinions of their experts, had always been powerless.

\section{ConcLusion}

The few cases discussed above can give only an incomplete idea of the role played in fact by the Court in the functioning of the Community, as compared to the role assigned to it by the Treaty. Nevertheless, one striking fact stands out quite clearly: The Court's role has undoubtedly been more important than had been foreseen; and, above all, it has been considerably different from that which had been visualized originally.

The authors of the Treaty conceived of the Court of Justice as the guardian of legality in the application of the Treaty, according to Western European concepts. According to these concepts, it belongs to the High Authority as the Executive responsible to a Parliamentary Assembly, to take the initiative and select the means by which to attain the aims of the Treaty. To this end, the Executive has been invested with considerable power. As a corollary of this, however, it is for the judge to ensure that this power is exercised within the limits laid down by the Treaty. Among the different tasks of the Court which have been outlined in the introductory part of this paper, the most important, according to the spirit of the Treaty, was most certainly the task of safeguarding Member States and enterprises against possible abuse of power on the part of the High Authority.

As a general rule, experience shows, however, that the only criticism that could possibly be leveled against the High Authority would not be that of having abused its power, but rather that of not having, in numerous cases, exercised its power with sufficient determination nor with sufficient promptness. In truth, the High Authority has not always been responsible for this situation; for instance, during 1959, the Council of Ministers did refuse its concurring opinion-required by article fiftyeight-for the introduction of production quotas, which the High Authority deemed to be temporarily required to face the coal crisis. It has, nevertheless, been excessively timid in cases where its powers obviously existed. Thus, in making its decisions relating to the compensatory arrangement introduced to enable Belgian coal mining to face the situation resulting from the common market created after the transitional five year period, the High Authority has not dared to lay down sufficiently selective criteria so as to concentrate efforts on those mines which were the most likely to become competitive ones with the aid of financial assistance. The Court has been led to admit implicitly that such a selective policy would not have been illegal. ${ }^{47}$ Evidently, the failure-now generally acknowledged-to integrate the Belgian coal industry into the common market during the transitional period has contributed to

${ }^{47}$ Dec. Nos. 8/55, 9/55, Nov. 29, 1956, 2 REC. 29I-325 (1955-56). 
the universal proportions of today's coal crisis, which has become a problem affecting the very structure of the economy. The Belgian coal problem is rendered more difficult to solve because the High Authority is now no longer entitled to use the exceptional measures which were at its disposal during the transitional period.

A further example to illustrate the insufficiently vigorous and speedy application of Treaty rules may be taken from the coal industry in connection with the problem of organizing collective sales groups of coal from the Ruhr and ensuring that such groups conform to the Treaty's anti-trust legislation. ${ }^{48}$ Since the Treaty entered into force, no satisfactory solution for this problem has been found; and this has enabled the interested groups to consolidate their position. It goes without saying that today, in the midst of a general coal crisis, solution of the problem has not become any easier. ${ }^{49}$

This state of affairs is in part explained by the influence of the Council of Ministers on decisions of the High Authority which, as has already been set out, ${ }^{50}$ is greater than had been provided for by the Treaty. In addition to the influence of states which is thus manifested through the Council, the influence of powerful professional "pressure groups"-whose aims concern practical results, rather than the orthodox application of the Treaty-makes itself felt. However, the consequence of this development has been the increasing importance of the role played by the Court of Justice. The latter is responsible for the correct application of the Treaty and may not ignore the principles and rules which it contains. This fact only increases its responsibility for the functioning of the Community; and there are voices which talk of the prospect of a "Government by Magistrates." Doubtless, this would be farfetched. For our part, we believe that, whatever may be the Court's desire to take account of economic and political reality and to foster a harmonious development of the Community, the Court cannot neglect its basic duty, which is that of defending the Treaty. As a judge of legality, it has no other choice but to leave the responsibility for its own actions to the High Authority, and to leave it to the governments. to decide on such amendments to the Treaty as they may deem necessary.

${ }^{18}$ E.C.S.C. Treaty art. 65.

${ }^{40}$ It ought not to be forgotten that the Court is called in only a posteriori and if a case has been submitted to it. Despite its endeavor, as we have seen, to open its forum in the largest possible way, it sometimes happens that essential issues are not submitted to it or that they are submitted in a more or less incidental way, which does not allow for a judgment on the very merits of the case. This is what happened in the case of the organization for the common sale of Ruhr coal. On this matter, several interesting cases were submitted to the Court, but the only one which would have really allowed for a well-timed judgment on the main issue was withdrawn before judgment. This appeal had been lodged by Italian steel producers, but after being granted some satisfaction by the organizations involved, they withdrew their action. Ansaldo Coke et al. v. Haute Autorité, case filed under No. 4/56. The appeal had been lodged against the High Authority's decision of Feb. 15, 1956, authorizing the sale in common of Ruhr coal by three sale agencies, under supervision of a common board; that decision still underlies the actual organization. Certainly, the Court alone cannot secure the Treaty's enforcement against an actual: agreement of the High Authority, of the Governments, and of the enterprises.

${ }^{\circ 0}$ See II(A) supra. 